\title{
ANALISIS LAHAN KRITIS DAN ARAHAN REHABILITASI LAHAN DALAM PENGEMBANGAN WILAYAH KABUPATEN KENDAL JAWA TENGAH
}

\author{
Analysis of Critical Land and Recomendation for Land Rehabilitation \\ In The Regional Development In Kendal, Central Java
}

Dinik Indrihastuti ${ }^{1}$, Kukuh Murtilaksono $^{2}$, Boedi Tjahjono ${ }^{3}$

Diterima: 27 April 2016 Disetujui: 10 Oktober 2016

\begin{abstract}
Abstrak: Dampak dari lahan kritis adalah penurunan kualitas tanah, disamping penurunan fungsi konservasi, produksi, dan kehidupan sosial ekonomi masyarakat. Tujuan dari penelitian ini adalah untuk menganalisis dan memetakan lahan kritis, mengkaji keterkaitan sebaran lahan kritis pada pola ruang dan membuat arahan rehabilitasi dalam pengembangan wilayah di Kabupaten Kendal. Pemilihan parameter penyebab terjadinya lahan kritis berdasarkan parameter P. 4/V-Set/2013 dan paremeter modifikasi, kemudian dilakukan pengolahan data tabular dan analisis SIG. Luas lahan kritis yang dihasilkan pada parameter P. 4/V-Set/2013 dan paremeter modifikasi berturut-turut adalah 19.535,96 ha dan 34.317,87 ha. Rehabilitasi lahan dilakukan melalui kegiatan konservasi vegetatif (reboisasi, penghijauan dan pengkayaan jenis tanaman) dan konservasi sipil teknis untuk mencegah erosi dan sedimentasi (pembuatan bangunan dam pengendali, dam penahan, terasering, saluran pembuangan air, sumur resapan, embung, rorak, dan biopori). Arahan untuk pengembangan wilayah di kawasan hutan melalui pengembangan PHBM (agroforestry, hutan rakyat, ekowisata dan wanafarma). Pada kawasan budidaya terutama pada lahan terlantar melalui optimalisasi hutan rakyat. Rehabilitasi bertujuan untuk mengendalikan lahan kritis dan meningkatkan pendapatan masyarakat dengan menjual produk dari hutan rakyat.
\end{abstract}

\section{Kata kunci:lahan kritis, pengembangan wilayah, rehabilitasi.}

\begin{abstract}
The impact of critical land create reduction quality of soil characteristics, which can interfere by the function of conservation, production, economic, and social life of the community. The objectives of this research were to analyze and map of critical land, review relevance of critical land distribution to the spatial pattern and make direction of rehabilitation in regional development in Kendal. The analytical methode which were applied in this study were selecting parameters of critical land and map overlaying by using GIS in to map distribution of critical land. The result of this research were for the critical land area in modification parameter was $34.317,87$ ha, and parameter of P. 4/V-Set/2013 was 19.535,96 ha, that scattered on every spatial pattern. General direction of land rehabilitation were vegetative conservation activity and technical civil conservation for erosion and sedimentation control. Direction of regional development in forest area was to develop PHBM through activity of agroforestry, community forest, ecotourism and medicinal plant cultivation in the forest. Direction on the farm cultivation area, especially on badland and yards, were optimization of community forest, by planting activities using perennials plant, MPTS and fruits plant, to control critical land, soil conservation and water management as well as increase community incomes by selling products from community forests.
\end{abstract}

Keywords: critical land, regional development, rehabilitation.

\footnotetext{
${ }^{1}$ Program Studi Ilmu Perencanaan Wilayah, Sekolah Pascasarjana Institut Pertanian Bogor
} 



\section{PENDAHULUAN}

Degradasi lahan adalah proses penurunan produktivitas lahan yang sifatnya sementara maupun tetap yang dicirikan dengan penurunan sifat fisik, kimia dan biologi. Lahan kritis merupakan salah satu bentuk dari lahan terdegradasi ((Dariah et al. 2004) ${ }^{1}$. Pengertian lahan kritis antara suatu lembaga dengan lembaga lainya berbeda-beda. Dari sudut pandang pertanian memandang lahan kritis dikaitkan dengan produksinya (produksi) sedangkan dari sudut pandang kehutanan lahan kritis dikaitkan dengan fungsi sebagai media pengatur tata air, media produksi hasil hutan dan sebagai media proteksi banjir dan/atau sedimentasi bagian hilir (Didu 2001)2.

Kabupaten Kendal memiliki kondisi topografi yang cukup beragam dimana terdapat perbukitan, dataran rendah dan dataran pesisir. Menurut Dinas Pertanian, Perkebunan dan Kehutanan Kabupaten Kendal bahwa pada tahun 2009 sampai dengan 2013, pada wilayah bagian selatan memiliki sebaran lahan kritis lebih banyak jika dibandingkan dengan kawasan dataran dan pesisir, kawasan tersebut merupakan perbukitan dengan dominasi kemiringan lereng adalah 8-15 \%, 15-25 \%dan > 40\%. Meningkatnya jumlah penduduk baik kelahiran maupun migrasi di wilayah Kendal bagian utara menyebabkan kebutuhan akan tanah juga meningkat. Sedangkan jumlah tanah tidak dapat ditambah sehingga menggeser fungsi lahan tersebut. Peningkatan jumlah penduduk tiap tahunnya mendorong terjadinya perubahan penggunaan lahan sehingga memicu peningkatan luasan lahan kritis dari tahun ke tahun.

Tahun 2013 luasan lahan kritis yang meliputi kelas "sangat kritis", "kritis" dan "agak kritis" seluas 10.866,5 ha yang berada pada kawasan budidaya pertanian adalah 8.927,5 ha, kawasan lindung di luar kawasan hutan 1.488,2 ha, kawasan hutan lindung 291,3 ha dan kawasan hutan produksi 159,5 ha (Dinas Pertanian Perkebunan dan Kehutanan Kabupaten Kendal 2014) $)^{3}$. Terjadinya lahan kritis disebabkan oleh beberapa faktor antara lain penutupan lahan, kemiringan lereng, faktor fisik dan kimia tanah (tekstur tanah, struktur tanah, permeabilitas tanah, bahan organik tanah) bobot isi tanah, produktivitas dan manajemen.

Pemerintah (Kementerian Kehutanan) mencanangkan kegiatan rehabilitasi hutan dan lahan (RHL) untuk mengatasi lahan kritis, memulihkan, mempertahankan, dan meningkatkan fungsi hutan dan lahan sehingga daya dukung, produktivitas dan peranannya sebagai penyangga kehidupan tetap terjaga. Penelitian ini bertujuan untuk : 1) menganalisis tingkat kekritisan lahan; 2) menkaji keterkaitan sebaran lahan kritis terhadap rencana pola ruang; 3) arahan rehabilitasi lahan dalam pengembangan wilayah berdasarkan pemetaan lahan kritis di Kabupaten Kendal.

\section{BAHAN DAN METODE}

\section{Lokasi dan Waktu Penelitian}

Penelitian ini dilaksanakan di Kabupaten Kendal, Provinsi Jawa Tengah yang terdiri dari 20 kecamatan dan terletak pada titik koordinat $109^{\circ} 40^{\prime}-110^{\circ} 18^{\prime}$ Bujur Timur dan $6^{\circ}$ $32^{\prime}-7^{\circ} 24^{\prime}$ Lintang Selatan. Penelitian dilaksanakan pada bulan April sampai dengan Desember 2015. 


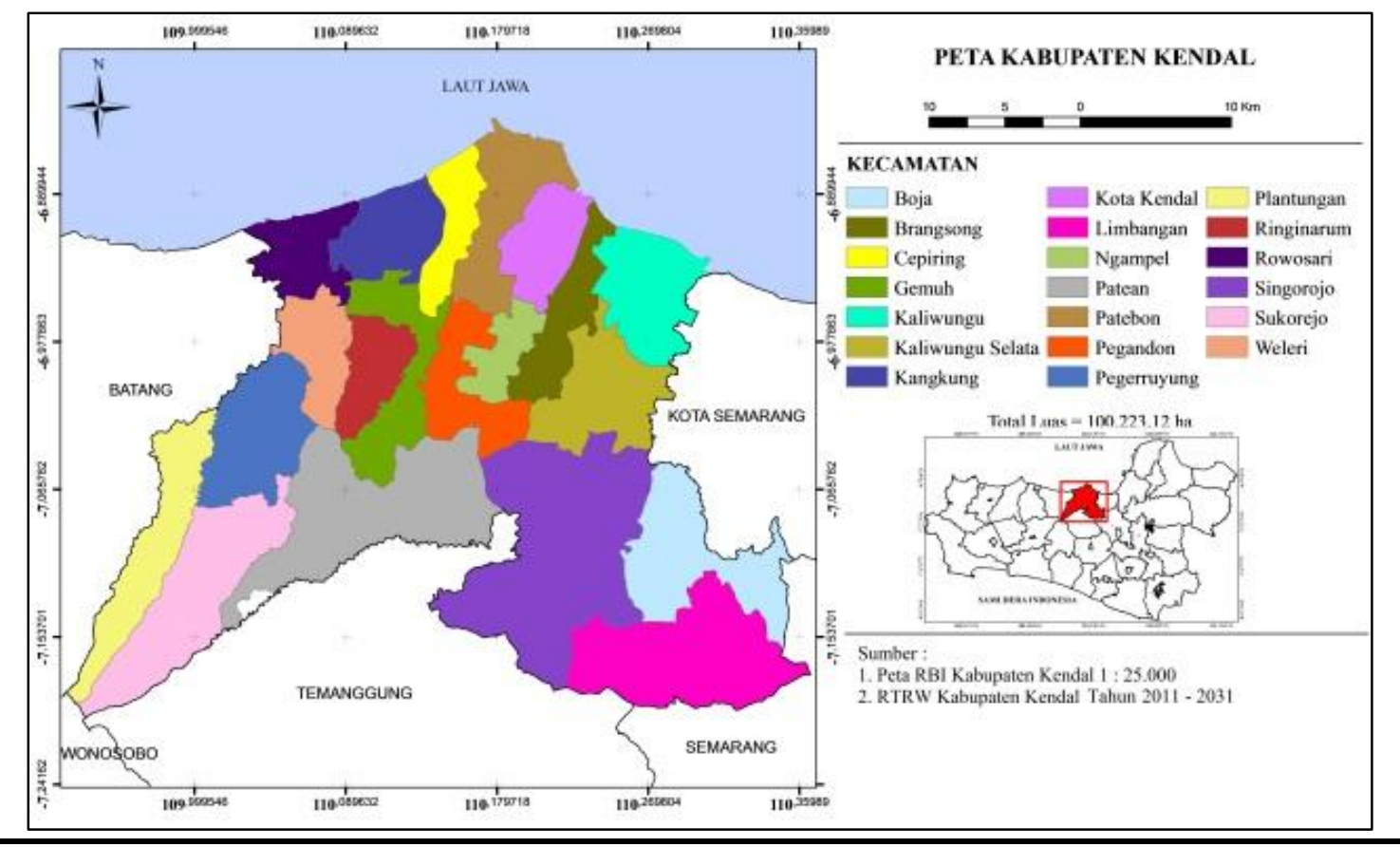

Gambar 1 PetaKabupaten Kendal

\section{Jenis dan Sumber Data}

Data yang digunakan dalam penelitian ini terdiri atas data primer dan data sekunder. Data primer diperoleh melalui survei lapang dengan pengambilan contoh tanah dan dokumentasi sebagai verifikasi dan validasi dari analisis penggunaan lahan dan lahan kritis. Validasi bertujuan untuk mengecek kebenaran, ketepatan dan kenyataan di lapangan. Di samping itu, data primer diperoleh melalui wawancara terhadap stakeholder pengelola lahan, tentang perubahan penggunaan lahan dan terbentuknya lahan kritis. Data sekunder yang diperoleh dari berbagai sumber termasuk studi pustaka, koordinasi dan konsultasi dengan berbagai instansi terkait lahan kritis dan kegiatan rehabilitasi hutan dan lahan. Bahan kuantitatif yang digunakan berupa peraturan Perundang-undangan,Peraturan Daerah terkait RTRW Kabupaten Kendal, data dari BPS Kabupaten Kendal, data dari Bappeda Kabupaten Kendal, Dinas Pertanian, Peternakan, Perkebunan dan Kehutanan Kabupaten Kendal, BPDAS Pemali Jratun, dan instansi lain yang berkaitan dengan data yang diperlukan .

\section{Bahan dan Alat}

Bahan dan alat yang digunakan dalam penelitian ini meliputi Data RTRW Kabupaten Kendal, GPS, kamera digital dan seperangkat komputer yang dilengkapi dengan Software: ArcGIS, Google Earth, Micrososft Excel.

\section{Analisis Data}

\section{Analisis dan Pemetaan Tingkat Kekritisan Lahan}

Kegiatan survei lapang dilakukan untuk pengecekan data spasial fisik terhadap keadaan sekarang yang ada di lapangan dan pengambilan sampel tanah sebanyak 30 titik 
yang mewakili tiap jenis tanah, kelerengan, dan masing-masing jenis penutupan/penggunaan lahan. Hasil uji laboratorium sampel tanah berupa struktur tanah, tekstur tanah, permeabilitas tanah, persentase bahan organik tanah dan bobot isi yang digunakan untuk menentukan tingkat erodibilitas tanah.

Untuk mengidentifikasi dan memetakan lahan kritis dan pemetaannya dilakukan melalui proses tumpang tindih (overlay) dalam operasi Sistem Informasi Geografis (SIG) terhadap peta-peta tematik (data sekunder) yang ada yaitu peta penutupan lahan, peta kemiringan lereng, peta tingkat bahaya erosi, peta pengelolaan lahan (peta manajemen dan peta produktivitas), erosivitas hujan (R), erosi yang diperbolehkan (Edp) dan erodibilitas (K). Penentuan lahan kritis dengan menggunakan parameter P.4/V-Set/20134 terdiri dari penutupan lahan, kemiringan lereng, tingkat bahaya erosi, manajemen dan produktivitas. Pada parameter tersebut terdapat perhitungan berulang pada kemiringan lereng dan penggunaan lahan yang sebenarnya sudah dihitung pada saat menentukan nilai erosi dengan persamaan USLE. Karena adanya perhitungan berulang maka pada penelitian ini menggunakan parameter modifikasi untuk mebandingkan luasan lahan kritis yang terbentuk Perbandingan antara kedua parameter tersebut dapat dilihat pada Tabel 1.

Tabel 1 Matriks perbandingan parameter penentu tingkat kekritisan lahan

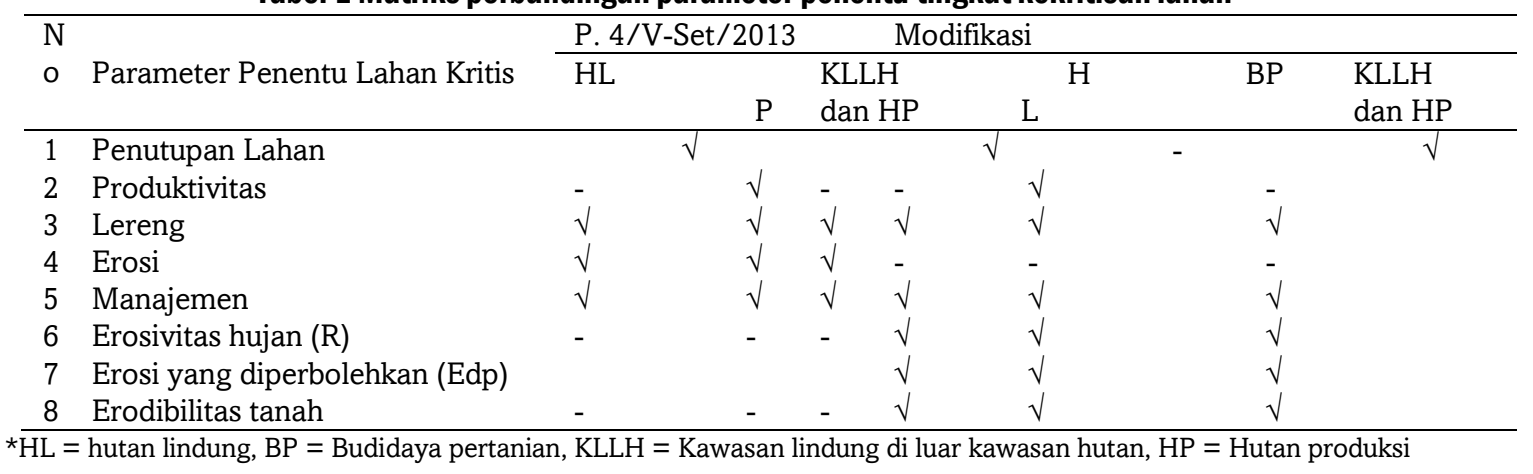

Lahan kritis yang akan digunakan untuk analisis selanjutnya hanya menggunakan "sangat kritis", "kritis" dan "agak kritis".

\section{Parameter penentu tingkat kekritisan lahan berdasarkan Perdirjen BPDAS PS Nomor P.4/V- Set/2013}

Parameter penentu lahan kritis berdasarkan Perdirjen BPDAS PS Nomor P. 4/VSet/2013 adalah :

1. Penutupan lahan tahun 2014.

2. Kemiringan lereng.

3. Tingkat Bahaya Erosi (TBE) (Tabel 2).

Erosi dihitung dengan rumus Universal Soil Loss Equation (USLE), yaitu :

$$
A=R \times K \times L S \times C \times P
$$

Dimana :

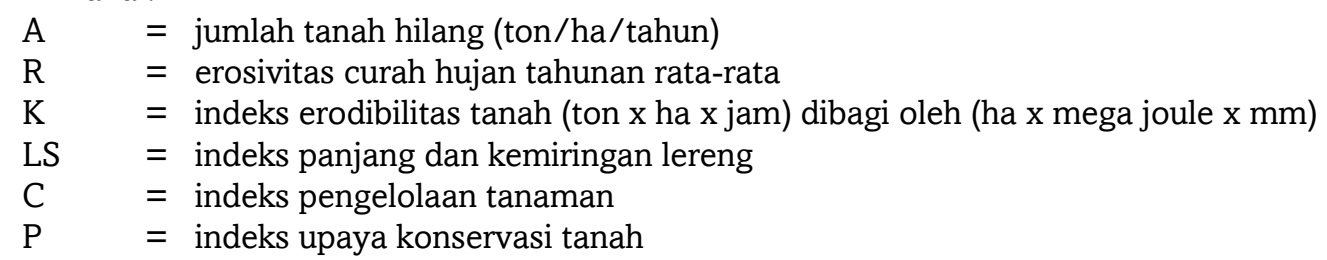


Tabel 2 Skor, Bobot Dan Nilai Parameter Kemiringan Lereng

\begin{tabular}{lccc}
\hline \multicolumn{1}{c}{ Kriteria } & Skor & Bobot & $\begin{array}{c}\text { Nilai } \\
\text { (Bobot x Skor) }\end{array}$ \\
\hline Datar (0-8 \%) & 5 & 24 & 119 \\
Landai (8-15 \%) & 4 & 24 & 96 \\
Agak Curam (15-25\%) & 3 & 24 & 72 \\
Curam (25-40\%) & 2 & 24 & 48 \\
Sangat Curam $(>40 \%)$ & 1 & 24 & 24 \\
\hline
\end{tabular}

4. Produktivitas

5. Manajemen

Skoring dan pembobotan pada tiap parameter untuk pemetaan lahan kritis berdasarkan Perdirjen BPDAS PS P.4/V-Set/2013 (Tabel 3).

Tabel 3 Skoring Dan Pembobotan Untuk Pemetaan Lahan Kritis Berdasarkan Perdirjen BPDAS PS P.4/V-Set/2013

\begin{tabular}{|c|c|c|c|c|}
\hline \multirow[t]{2}{*}{ No } & \multicolumn{3}{|l|}{ Total Skor Pada: } & \multirow{2}{*}{$\begin{array}{l}\text { Tingkat kekritisan } \\
\text { lahan }\end{array}$} \\
\hline & $\begin{array}{l}\text { Kawasan hutan } \\
\text { lindung }\end{array}$ & $\begin{array}{l}\text { Kawasan budidaya } \\
\text { pertanian }\end{array}$ & $\begin{array}{l}\text { Kawasan lindung di luar } \\
\text { kawasan hutan dan } \\
\text { hutan produksi }\end{array}$ & \\
\hline 1 & $120-180$ & $115-200$ & $110-200$ & Sangat Kritis \\
\hline 2 & $181-270$ & $201-275$ & $201-275$ & Kritis \\
\hline 3 & $271-360$ & $276-350$ & $276-350$ & Agak Kritis \\
\hline 4 & $361-450$ & $351-425$ & $351-425$ & Potensial Kritis \\
\hline 5 & $451-500$ & $426-500$ & $426-500$ & Tidak Kritis \\
\hline
\end{tabular}

\section{Parameter Penentu Lahan Kritis Modifikasi dari P. 4/V-Set/2013}

Analisis sebaran lahan kritis pada tahun 2014 dengan parameter modifikasi menggunakan parameter yang terdiri dari penutupan lahan, kemiringan lereng, erosivitas hujan, erosi yang diperbolehkan, erodibilitas tanah, manajemen dan produktivitas, penggunaaan parameter pada tiap kawasan disajikan pada Tabel 4.

Tabel 4 Parameter Penentu Kekritisan Lahan (Parameter Modifikasi)

\begin{tabular}{lllll}
\hline No & Parameter modifikasi & HL & BP & KLLH dan HP \\
\hline 1 & Penutupan Lahan & $\sqrt{ }$ & - & $\sqrt{ }$ \\
2 & Kemiringan Lereng & $\sqrt{ }$ & $\sqrt{ }$ & $\sqrt{ }$ \\
3 & Erosivitas Hujan (R) & $\sqrt{ }$ & $\sqrt{ }$ & $\sqrt{ }$ \\
4 & Erosi yang diperbolehkan (EDP) & $\sqrt{ }$ & $\sqrt{ }$ & $\sqrt{ }$ \\
5 & Erodibilitas Tanah (K) & $\sqrt{ }$ & $\sqrt{ }$ & $\sqrt{ }$ \\
6 & Manajemen & $\sqrt{ }$ & $\sqrt{ }$ & $\sqrt{ }$ \\
7 & Produktivitas & - & $\sqrt{ }$ & - \\
\hline
\end{tabular}

Parameter modifikasi untuk pembobotan dihitung dengan persamaan :

$$
\begin{array}{ll}
\text { Dimana } & \\
\mathrm{Wj} & =\text { Bobot yang dinormalkan; } \\
\mathrm{n} & =\text { Jumlah parameter } \\
\mathrm{rj} & =\text { Urutan parameter. }
\end{array}
$$$$
W j=\frac{n-r j+1}{\Sigma(n-r j+1)}
$$

Untuk parameter penentu pertama pada pembentukan lahan kritis adalah parameter penutupan/penggunaan lahan, karen faktor tersebut merupakan penyebab 
terjadinya degradasi lahan. Untuk parameter selanjutnya adalah kemiringan lereng, erosivitas hujan (R), erosi yang diperbolehkan (EDP), erodibilitas (K) dan manajemen. Hasil pembobotan sesuai tingkat kepentingan dapat dilihat pada Tabel 5.

Tabel 5 Urutan Parameter Penentu Dan Bobot

\begin{tabular}{|c|c|c|c|c|c|}
\hline No & Parameter penentu & (rj) & $(n-r j+1)$ & $(\mathrm{Wj})$ & $\% \mathrm{Wj}$ \\
\hline 1 & Penutupan lahan (dan produktivitas ${ }^{\star}$ ) & 1 & 6 & 0,29 & 29 \\
\hline 2 & Kemiringan lereng & 2 & 5 & 0,24 & 24 \\
\hline 3 & Erosivitas hujan (R) & 3 & 4 & 0,19 & 19 \\
\hline 4 & Erosi yang diperbolehkan (EDP) & 4 & 3 & 0,14 & 14 \\
\hline 5 & Erodibilitas tanah $(\mathrm{K})$ & 5 & 2 & 0,09 & 9 \\
\hline 6 & Manajemen & 6 & 1 & 0,05 & 5 \\
\hline $\mathrm{n}=6$ & & & 21 & 1 & 100 \\
\hline
\end{tabular}

1. Penutupan Lahan, penilaian menggunakan data tutupan lahan yang dihasilkan dari Citra Landsat Tahun 2014 (Tabel 6).

Tabel 6 Skor, bobot dan nilai parameter pengunaan lahan

\begin{tabular}{llll}
\hline Kriteria & Skor & $\begin{array}{l}\text { Bob } \\
\text { ot }\end{array}$ & Nilai (Bobot x Skor) \\
\hline Sangat baik & 5 & 29 & 143 \\
Baik & 4 & 29 & 114 \\
Sedang & 3 & 29 & 86 \\
Buruk & 2 & 29 & 57 \\
Sangat & 1 & 29 & 29 \\
buruk & & & \\
\hline
\end{tabular}

2. Kemiringan Lereng, penilaian lereng menggunakan data dari Dinas DCKTR Kabupaten Kendal (2009), dengan klasifikasi dan skoring mengacu pada P. 4/V-Set/2013 (Tabel 7)

\begin{tabular}{llll}
\hline Kriteria & Sko & Bobo & Nilai (Bobot x Skor) \\
& $\mathrm{r}$ & $\mathrm{t}$ & \\
\hline Datar $(0-8 \%)$ & 5 & 24 & 119 \\
Landai $(8-15 \%)$ & 4 & 24 & 96 \\
Agak Curam $(15-25 \%)$ & 3 & 24 & 72 \\
Curam $(25-40 \%)$ & 2 & 24 & 48 \\
Sangat Curam $(>40 \%)$ & 1 & 24 & 24 \\
\hline
\end{tabular}

3. Erosivitas Hujan, dihitung dengan persamaan Lenvain (1975) dalam Hardjowigeno $(2007)^{5}$ sebagai berikut :

$$
\mathrm{RM}=2,21(\text { Rain })_{\mathrm{m}}^{1,36}
$$

Dimana :

$\begin{array}{lll}\mathrm{RM} & = & \text { Erosivitas hujan bulanan } \\ (\text { Rain })_{\mathrm{m}} & = & \text { Curah hujan bulanan }(\mathrm{cm})\end{array}$

Tabel 8 Skor, Bobot Dan Nilai Parameter Erosivitas Hujan (Dalam Cm)

\begin{tabular}{llll}
\hline Kriteria & Skor & Bobot & Nilai (Bobot x Skor) \\
\hline Rendah $<1160 \mathrm{~cm} /$ thn & 5 & 19 & 95 \\
Sedang $(1160-2013 \mathrm{~cm} / \mathrm{thn})$ & 4 & 19 & 76 \\
Agak tinggi $(2013-2977 \mathrm{~cm} / \mathrm{thn})$ & 3 & 19 & 57 \\
Tinggi $(2977-4033 \mathrm{~cm} /$ thn $)$ & 2 & 19 & 38 \\
Sangat tinggi $(>4033 \mathrm{~cm} / \mathrm{thn})$ & 1 & 19 & 19 \\
\hline
\end{tabular}


Data Spasial erosivitas hujan disusun dari hasil pengolahan data curah hujan sekunder selama sepuluh tahun terakhir yaitu tahun 2005 - 2014 pada 5 (lima) stasiun pengamatan di Kabupaten Kendal , dengan sumber data dari Dinas Pertanian, Perkebunan dan Kehutanan Kabupaten Kendal (2014). Pengolahan data curah hujan menghasilkan informasi mengenai erosivitas hujan yang dapat dilakukan dengan manual maupun dengan bantuan computer

4. Erosi yang Diperbolehkan (EDP), adalah jumlah tanah hilang yang diperbolehkan per tahun supaya produktivitas suatu lahan tidak berkurang sehingga tanah tetap produktif secara lestari (Hardjowigeno 2007). EDP dihitung dengan persamaan dari Wood dan Dent (1983) dalam Hardjowigeno (2007)6 sebagai berikut :

$\begin{array}{lll}\text { EDP } \mathrm{mm} / \text { thn } & =\left[\frac{\mathrm{DE}-\mathrm{Dmin}}{\text { Kelestarian Tanah }}\right]+\text { Kecepatan pembentukan tanah } \\ \mathrm{DE} & = & \text { Kedalaman Efektif } \mathrm{x} \text { Faktor Kedalaman } \\ \mathrm{EDP} \text { ton/ha/thn } & = & \text { EDP mm/thn } \mathrm{x} 10 \text { ton/ha } \mathrm{BD} \\ \text { Dimana : } & = & \\ \mathrm{DE} & = & \text { Kedalaman ekuivalen tanah } \\ \mathrm{BD} & = & \text { Kedalaman tanah minimum untuk perakaran tanaman } \\ \text { Dmin } & \end{array}$

Kecepatan pembentukan tanah, 1,5 mm/thn (latosol dan mediteran) dan $1 \mathrm{~mm} / \mathrm{thn}$ (alluvial,andosol, dan litosol).

Hasil EDP dinyatakan dalam $\mathrm{mm} /$ thn atau ton/ha/thn. Data yang digunakan untuk menenttukan nilai EDP adalah data sekunder berupa kedalaman efektif tanah dan kedalaman minimum tanah (Bappeda Kabupaten Kendal 2011)6, sedangkan untuk bobot isi menggunakan data primer yang diperoleh dari lapangan. Arsyad (2010)7 berpendapat bahwa nilai EDP maksimum untuk tanah di Indonesia terutama tanah yang dalam adalah 25 ton/ha/tahun, sedangkan untuk tanah yang kedalamannya kurang maka EDP harus kurang dari 25 ton/ha/tahun (Tabel 9).

Tabel 9 Skor, Bobot Dan Nilai Parameter EDP

\begin{tabular}{llll}
\hline Kriteria & Skor & Bobot & Nilai (Bobot x Skor) \\
\hline $\begin{array}{l}\text { Tinggi }> \\
\text { ton/ha/tahun }\end{array}$ & 5 & 14 & 70 \\
$\begin{array}{l}\text { Rendah < } 25 \\
\text { ton/ha/tahun }\end{array}$ & 1 & 14 & 14 \\
\hline
\end{tabular}

Erodibilitas Tanah, data-data yang diperlukan dalam penilaian parameter erodibilitas tanah dan bobot isi tanah antara lain : tekstur tanah (dalam fraksi debu, pasir sangat halus dan pasir), persentase bahan organik, struktur tanah, permeabilitas tanah. Dimana data-data primer terkait erodibilitas tanah tersebut di atas dilakukan dengan mengambil contoh tanah di lokasi peneltian untuk kemudian dilakukan uji laboratorium.Skor, bobot dan nilai parameter erodibilitas tanah dapat diliat pada Tabel 10. Perhitungan nilai $\mathrm{K}$ dihitung dengan persamaan (Weischmeier et al. 1971 dalam Hardjowigeno 2007)6:

$$
\mathrm{K}=1,292\{2,1 \mathrm{M} 1,14(10-4)(12-\mathrm{a})+3,25(\mathrm{~b}-2)+2,5(\mathrm{c}-3)\} / 100
$$




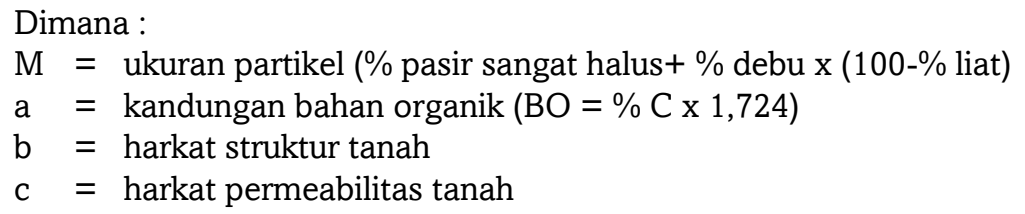

Tabel 10 Skor, Bobot Dan Nilai Parameter Erodibilitas Tanah

\begin{tabular}{llll}
\hline Kriteria & Skor & Bobot & Nilai (Bobot x Skor) \\
\hline Rendah $(<0,20)$ & 5 & 9 & 95 \\
Sedang $(0,21-0,32)$ & 4 & 9 & 76 \\
Agak tinggi $(0,33-0,40)$ & 3 & 9 & 57 \\
Tinggi $(0,41-0,55)$ & 2 & 9 & 38 \\
Sangat Tinggi $(0,56-0,64)$ & 1 & 9 & 19 \\
\hline
\end{tabular}

5. Manajemen, penilaiannya dilakukan pada kawasan hutan lindung, kawasan budidaya pertanian, kawasan lindung di luar kawasan hutan dan kawasan hutan produksi. Data terkait manajemen diperoleh dari BPDAS PS Kementerian Kehutanan tahun 2013. Skoring, pembobotan dan nilai pada parameter manajemen berdasarkan pada P.4/VSet/2013 (Tabel 11).

Tabel 11 Skor, Bobot Dan Nilai Parameter Manajemen

\begin{tabular}{llll}
\hline Kriteria & Skor & Bobot & $\begin{array}{l}\text { Nilai } \\
\text { (Bobot x Skor) }\end{array}$ \\
\hline Baik : & 5 & 5 & 25 \\
Kawasan lindung dan hutan produksi : lengkap, tata batas & & & \\
kawasan ada, pengamanan kawasan ada dan penyuluhan & & & \\
dilaksanakan & & & \\
Kawasan budidaya pertanian : Penerapan teknologi & & & \\
konservasi tanah lengkap dan sesuai petunjuk & 3 & 5 & 15 \\
Sedang (tidak lengkap) & 1 & 5 & 5 \\
Buruk (tidak ada) & &
\end{tabular}

Produktivitas, penilaian produktivitas pada penentuan lahan kritis di Kabupaten Kendal dilakukan berdasarkan rasio terhadap produksi komoditi umum optimal pada pengelolaan tradisional. Data yang digunakan merupakan data sekunder dari Dinas Pertanian, Perkebunan dan Kehutanan Kabupaten Kendal (2014) dan BPDAS PS Pemali Jratun (2014). Skoring, bobot dan nilai mengacu pada P.4/V-Set/2013 (Tabel 12).

Tabel 12 Skor, Bobot Dan Nilai Parameter Produktivitas

\begin{tabular}{llll}
\hline Kriteria & Skor & Bobot & Nilai (Bobot x Skor) \\
\hline Sangat tinggi & 5 & 29 & 143 \\
tinggi & 4 & 29 & 114 \\
Sedang & 3 & 29 & 86 \\
Rendah & 2 & 29 & 57 \\
Sangat rendah & 1 & 29 & 29 \\
\hline
\end{tabular}

6. Pemberian skoring parameter lahan kritis pada parameter modifikasi mengacu pada Perdirjen BPDAS PS P. 4/V-Set/2013 dibuat dalam 5 kelas. Tingkat bahaya lahan kritis akan dibagi menjadi 5 (lima) kelas yaitu : tidak kritis, potensial kritis, agak kritis, kritis dan sangat kritis dengan menggunakan interval kelas yang digunakan yakni (Dibyosaputro 1999 dalam Kubangun 2015)8 :

$$
\text { Interval kelas }=\frac{\text { nilai tertinggi }- \text { nilai terendah }}{\text { jumlah kelas }}
$$


Hasil dari interval ini selanjutnya digunakan untuk pengelompokan kelas (deliniası) pada data atribut dan data spasial analisis SIG. Selanjutnya untuk arahan rehabilitasi lahan dan pengembangan wilayah meliputi kelas "agak kritis", "kritis" dan "sangat kritis". Klasifikasi tingkat kekritisan lahan dan interval kelas dapat dilihat pada Tabel 13.

Tabel 13 Kelas Lahan Kritis Parameter Modifikasi

\begin{tabular}{clc}
\hline No & Kelas Lahan Kritis & Nilai \\
\hline 1 & Tidak kritis & $424-500$ \\
2 & Potensial kritis & $347-423$ \\
3 & Agak kritis & $270-346$ \\
4 & Kritis & $193-269$ \\
5 & Sangat Kritis & $115-192$ \\
\hline
\end{tabular}

Lahan kritis yang teridentifikasi menggunakan parameter P.4/V-Set/2013 dan parameter modifikasi dipilih salah satu, pemilihan kriteria lahan kritis dari keduanya didasarkan kritis yang lebih luas yang digunakan untuk analisis selanjutnya.

\section{Mengkaji Keterkaitan Sebaran Tingkat Kekritisan Lahan dengan Pola Ruang (RTRW)}

Pola ruang Kabupaten Kendal terbagi menjadi 2 (dua) kawasan yaitu, kawasan lindung seluas $12.736,21$ ha $(12,7 \%)$ dan kawasan budidaya seluas $87.486,91$ ha $(87,3 \%)$. Untuk mengetahui keterkaitan sebaran tingkat kekritisan lahan dengan pola ruang dilakukan overlay antara peta pola ruang Kabupaten Kendal tahun 2011 dengan peta lahan kritis teridentifikasi (2014), sehingga menghasilkan peta sebaran tingkat kekritisan lahan pada setiap pola ruang. Kemudian dilakukan analisis untuk melihat sebaran lahan kritis yang berada pada kawasan lindung dan kawasan budidaya. Apabila terdapat lahan kritis pada kawasan lindung maka perlu dilakukan perbandingan dengan kondisi tutupan/penggunaan lahan eksisting apakah sesuai dengan peruntukannya sebagai kawasan lindung atau tidak. Sedangkan jika terdapat lahan kritis pada kawasan budidaya maka perlu dilihat penggunaan lahan secara eksisiting dan pengolahan tanahnya.

\section{Menyusun Arahan Rehabilitasi dalam Pengembangan Wilayah Berdasarkan Analisis Pemetaan Lahan Kritis}

Pengembangan wilayah dapat dianggap sebagai suatu bentuk intervensi positif terhadap pembangunan di suatu wilayah (Rustiadi 2006) ${ }^{9}$. Penyusunan arahan rehabilitasi lahan untuk prioritas pertama pada lahan dengan kelas "sangat kritis", "kritis" dan "agak kritis" di kawasan lindung dan hutan produksi, kemudian kelas "sangat kritis" dan "kritis" pada kawasan budidaya (di luar kawasan hutan). Prioritas kedua pada kawasan budidaya(di luar kawasan hutan) dengan kelas "agak kritis".

Arahan rehabilitasi bisa dimanfaatkan oleh pihak-pihak terkait penanganan lahan kritis dalam memperbaiki arahan rehabilitasi hutan dan lahan yang sudah ada di Kabupaten Kendal, melalui kegiatan rehabilitasi lahan secara optimal diharapkan mampu meningkatkan produktivitas dari suatu lahan. Penyusunan arahan pengembangan wilayah berdasarkan pemetaan lahan kritis dilakukan seiring dengan kegiatan rehabilitasi lahan melalui pengembangan komoditas yang sesuai dengan kondisi wilayah dan kesesuaian penggunaan lahan pada pola ruang. Pengembangan wilayah di harapkan akan meningkatkan pendapatan masyarakat setempat sehingga alih fungsi lahan untuk kegiatan non pertanian bisa dihambat dan lahan kritis bisa teratasi serta mampu meningkatkan PDRB Kabupaten Kendal. 


\section{HASIL DAN PEMBAHASAN}

Analisis dan Pemetaan Lahan Kritis dengan Parameter dari Perdirjen BPDAS PS Nomor P. 4/VSet/2013 dan Parameter Modifikasi

Hasil analisis lahan kritis dengan parameter P. 4/V-Set/2013 menunjukkan bahwa luas lahan kritis berturut-turut adalah kawasan hutan lindung 471,97 ha, kawasan budidaya 17.368,34 ha, kawasan lindung di luar kawasan hutan 1.493,38 ha dan kawasan hutan produksi 202,38 ha. Lahan kritis di Kabupaten Kendal tahun 2014 dengan parameter P. 4/VSet/2013 seluas 19.535,96 ha (19,49\% dari total luas wilayah Kabupaten Kendal), secara rinci disajikan pada Tabel 14 dan sebaran lahan kritis dapat dilihat pada Gambar 1.

Tabel 14 Luas Lahan Kritis Tahun 2014 Dengan Parameter P. 4/V-Set/2013

\begin{tabular}{llrrrr}
\hline No & Kawasan & \multicolumn{1}{c}{ Sangat Kritis } & Kritis & Agak kritis & Total \\
\hline 1 & HL & 0,74 & 1,30 & 469,93 & 471,97 \\
2 & BP & 5,91 & $2.367,90$ & $14.994,53$ & $17.368,34$ \\
3 & KLLH & - & 983,50 & 509,88 & $1.493,38$ \\
4 & HP & 0,04 & 0,07 & 202,27 & 202,38 \\
\hline & Total (ha) & 6,65 & $3.352,70$ & $16.176,61$ & $19.533,96$ \\
\hline & $\%$ & 0,01 & 3,35 & 16,14 & 19,50 \\
\hline
\end{tabular}

Keberadaan lahan kritis seharusnya tidak terjadi karena pada hutan lindung yang memiliki fungsi perlindungan pada kawasan yang berada di bawahnya, jika permasalahan lahan kritis pada kawasan ini tidak segera ditangani maka jumlah luasan lahan kritis akan terus meningkat.

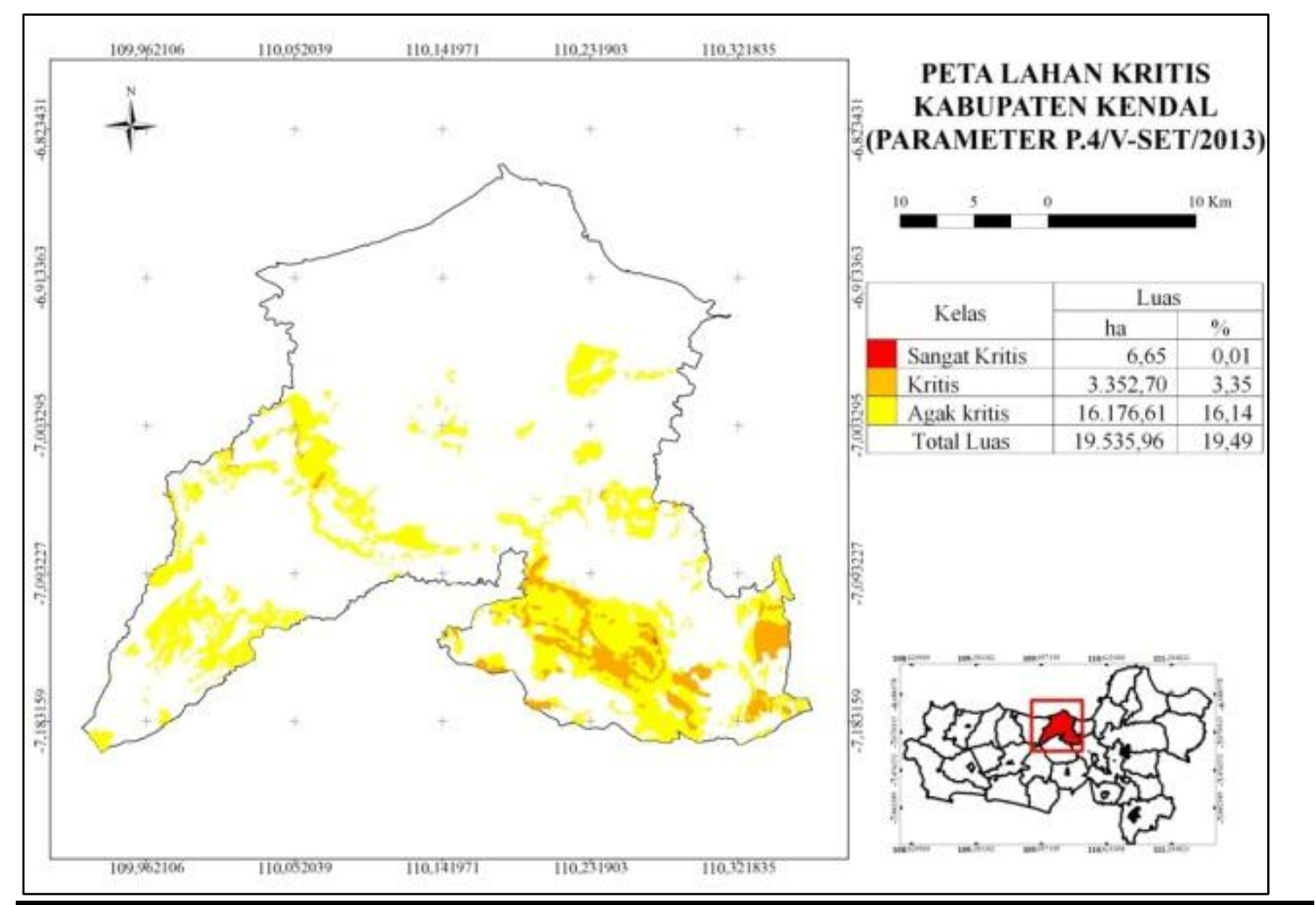

Gambar 1 Peta lahan kritis dengan parameter P.4/V-Set/2013

Pada kriteria parameter modifikasi menunjukkan bahwa luas lahan kritis berturutturut adalah kawasan hutan lindung 1.791,22 ha, kawasan budidaya 20.749,00 ha, kawasan 
lindung di luar kawasan hutan 3.946,73 ha dan kawasan hutan produksi 7.830,92 ha (Tabel 15), Luas lahan kritis tahun 2014 dengan parameter modifikasi seluas $34.317,87$ ha $(34,43 \%$ dari total luas wilayah Kabupaten Kendal) (Gambar 2). Berdasarkan hasil analisis maka dipilih luas lahan dengan parameter modifikasi dari Perdirjen BPDAS PS nomor P. 4/VSet/2013.

Tabel 15 Luas Lahan Kritis Tahun 2014 Dengan Parameter Modifikasi

\begin{tabular}{llllll}
\hline No & Kawasan & Sangat Kritis & Kritis & Agak kritis & Total \\
\hline 1 & HL & 0,67 & $1.147,72$ & 642.83 & $1.791,22$ \\
2 & BP & 13,90 & $2.193,67$ & $18.541,43$ & $20.749,00$ \\
3 & KLLH & 133,20 & $2.378,88$ & $1.434,65$ & $3.946,73$ \\
4 & HP & 8,10 & 922,74 & $6.900,08$ & $7.830,92$ \\
\hline & Total (ha) & 155,87 & $6.643,01$ & $27.518,99$ & $34.317,87$ \\
\hline$\%$ & 0,16 & 6,63 & 27,64 & 34,43 \\
\hline
\end{tabular}

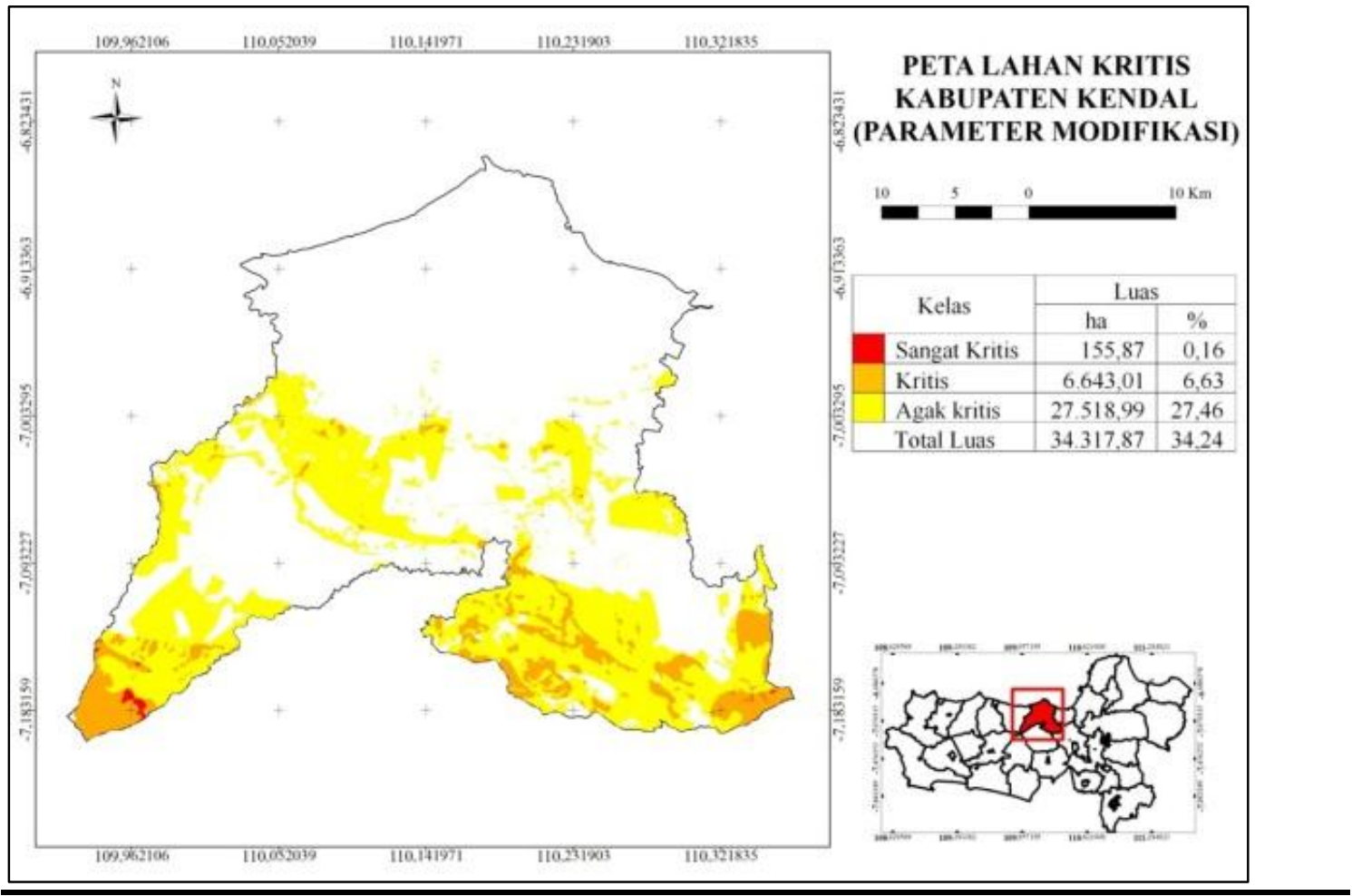

Gambar 2 Peta Lahan Kritis Dengan Parameter Modifikasi

Berdasarkan hasil analisis maka dipilih luas lahan dengan parameter modifikasi dari Perdirjen BPDAS PS nomor P. 4/V-Set/2013.

\section{Sebaran Lahan Kritis terhadap Pola Ruang}

Hasil analisis pada peta pola ruang dengan peta lahan kritis di Kabupaten Kendal disajikan pada Tabel 16, hampir semua kawasan dalam pola ruang terdapat sebaran lahan kritis, pada kawasan lindung terdapat lahan kritis seluas 4.678,92 ha dan pada kawasan budidaya terdapat lahan kritis seluas $29.638,95$ ha. Lahan kritis terbesar pada kawasan tanaman tahunan yaitu 11.956,29 ha, dan kawasan hutan produksi tetap, yaitu seluas $6.868,29$ ha. Lahan kritis terjadi karena penggunaan lahan yang tidak sesuai dengan 
peruntukannya, pada hutan lindung, kawasan perlindungan setempat (sempadan sungai, sempadan mata air, dan sempadan rel kereta api) dan hutan produksi terjadi perubahan penggunaan lahan menjadi semak belukar, kebun, empang, tegalan, sawah dan pemukiman.

Tabel 16 Sebaran Lahan Kritis Tahun 2014 Terhadap Pola Ruang Kabupaten Kendal (RTRW Tahun 2011).

\begin{tabular}{|c|c|c|c|c|c|}
\hline \multirow[t]{2}{*}{ No } & \multirow[t]{2}{*}{ Pola Ruang Tahun 2011} & \multicolumn{3}{|c|}{ Tingkat kekritisan } & \multirow[t]{2}{*}{ Total Luas (ha) } \\
\hline & & Sangat kritis & Kritis & Agak kritis & \\
\hline & Kawasan lindung & & & & \\
\hline 1 & Sempadan Mata Air & - & 4,98 & 82,60 & 87,58 \\
\hline 2 & Sempadan rel kereta api & - & - & 1,04 & 1,04 \\
\hline 3 & Hutan Lindung & 3,63 & $1.063,98$ & 604,33 & $1.671,94$ \\
\hline \multirow[t]{2}{*}{4} & Sempadan Sungai & 3,22 & 468,55 & $2.446,59$ & $2.918,36$ \\
\hline & Kawasan Budidaya & & & & \\
\hline 5 & Hutan Produksi Tetap & 2,16 & 373,54 & $6.492,59$ & $6.868,29$ \\
\hline 6 & Hutan Produksi Terbatas & 11,14 & 531,00 & 385,30 & 927,44 \\
\hline 7 & Permukiman & 13,23 & 243,53 & $1.463,60$ & $1.720,36$ \\
\hline 8 & Kawasan Tanaman Tahunan & 9,51 & $2.674,23$ & $9.272,55$ & $11.956,29$ \\
\hline 9 & Kawasan Holtikultura dan Perkebunan & 109,99 & 645,52 & $3.087,81$ & $3.843,32$ \\
\hline \multirow[t]{2}{*}{10} & Kawasan Tanaman Pangan & 2,99 & 637,68 & $3.682,58$ & $4.323,25$ \\
\hline & Total luas & 155,87 & $6.643,01$ & $27.518,99$ & $34.317,87$ \\
\hline
\end{tabular}

\section{Arahan Rehabilitasi Lahan dalam Pengembangan Wilayah Berdasarkan Pemetaan Lahan Kritis}

Berdasarkan Permenhut P.32/Menhut-II/200910 bahwa rehabilitasi hutan dan lahan mencakup 3 (tiga) aspek kegiatan yaitu upaya untuk memulihkan, mempertahankan dan meningkatkan fungsinya. Rehabilitasi lahan kritis di Kabupaten Kendal melalui kegiatan konservasi secara vegetatif dengan melakukan reboisasi, penghijauan, pengkayaan jenis tanaman dan konservasi secara sipil teknis (pembuatan bangunan dam pengendali, dam penahan, terasering, saluran pembuangan air, sumur resapan, embung, rorak, dan biopori) untuk mencegah erosi dan sedimentasi pada kawasan budidaya pertanian.

Kabupaten Kendal memiliki kawasan lindung seluas $12.736,21$ ha $(12,71 \%$ dari luas wilayah Kabupaten Kendal) dan kawasan budidaya seluas 87.486,91 ha (87,29\% dari luas wilayah Kabupaten Kendal). Setelah dilakukan analisis pemetaan lahan kritis dengan parameter-parameter terdiri dari : penutupan lahan, kemiringan lereng, erosivitas hujan, erosi yang diperbolehkan, erodibilitas tanah, manajemen, dan produktivitas diperoleh hasil bahwa pada kawasan lindung terdapat lahan kritis seluas 4.678,92 ha dan pada kawasan budidaya terdapat lahan kritis seluas 29.638,95 ha, lahan kritis tersebar di beberapa kecamatan yaitu Boja, Brangsong, Gemuh, Kaliwungu, Kaliwungu Selatan, Limbangan, Ngampel, Patean, Pegandon, Pagerruyung, Plantungan, Ringinarum, Singorojo, Sukorejo, dan Weleri.

Rehabilitasi pada kawasan hutan lindung bertujuan untuk memulihkan fungsi pokok sebagai perlindungan sistem penyangga kehidupan dan memulihkan kesuburan tanah. Rehabilitasi di hutan produksi bertujuan untuk meningkatkan produktivitas kawasan hutan produksi. Kawasan budidaya di luar kawasan hutan kegiatan rehabilitasi yang dilakukan dapat berupa penghijauan dengan pengkayaan jenis tanaman untuk meningkatkan produktifitas tanaman pangan dan perkebunan. Keberadaan pemukiman, sawah, tegalan dan kebun pada kawasan lindung dan kawasan hutan perlu ditertibkan, melalui pendekatan persuasif untuk tidak menggunakannya sebagai kawasan budidaya, upaya penggusuran ataupun relokasi ke tempat yang sudah disediakan dan upaya hukum.

Berdasarkan pertimbangan luasan lahan kritis yang tersebar pada hampir semua pola ruang di Kabupaten Kendal maka disusun arahan rehabilitasi lahan berdasarkan tingkat kekritisan lahan yang telah disusun dengan menggunakan parameter modifikasi. Arahan 
tersebut dapat digunakan untuk masukan pada instansi terkait dalam melakukan rehabilitasi hutan dan lahan serta arahan pengembangan wilayah Kecamatan di Kabupaten Kendal (Tabel 17 dan 18). Skala prioritas rehabilitasi lahan yang diutamakan pada kawasan lindung (kawasan hutan lindung dan kawasan perlindungan setempat) dan kawasan hutan produksi (tetap dan terbatas) dengan tingkat kekritisan lahan mulai dari "sangat kritis" hingga "agak kritis". Pada kawasan budidaya di luar kawasan hutan di prioritaskan pada kelas "sangat kritis" dan "kritis". Prioritas kedua untuk arahan rehabilitasi pada kawasan budidaya di luar kawasan hutan dengan kelas "agak kritis".

Tingkat kemiskinan menjadi penyebab kerusakan hutan lindung. Penebangan secara liar oleh masyarakat dilakukan untuk memenuhi kebutuhan hidup dan kebutuhan akan kayu bakar. Arahan rehabilitasi dalam pengembangan wilayah untuk menangani lahan kritis di hutan lindung Gunung Prahu (Kecamatan Plantungan dan Sukorejo) dan Gunung Ungaran (Kecamatan Boja dan Limbangan) adalah melalui kegiatan reboisasi dan pengayaan jenis tanaman. Kegiatan tersebut dilakukan antara masyarakat setempat dan instansi terkait. Pengembangan aspek sosial ekonomi dapat dilakukan melalui kegiatan Pengelolaan Hutan Bersama Masyarakat (PHBM) dengan pemanfaatan sumberdaya hutan melalui agroforestry, ekowisata, dan wanafarma.

Keberadaan pemukiman di kawasan hutan lindung di Desa Gonoharjo, Kecamatan Limbangan perlu di evaluasi oleh instansi-instansi terkait untuk mengetahui status permukiman tersebut. Dalam hal keberadaan permukiman tersebut memang sudah sangat lama, maka bisa dilakukan pengusulan alih fungsi lahan (Revisi RTRW). Seandainya permukiman tersebut baru saja ada maka perlu dilakukan penertiban tata batas kawasan hutan lindung. Upaya-upaya yang dapat dilakukan melalui pendekatan dan sosialisasi oleh instansi-instansi terkait terhadap masyarakat setempat terkait fungsi kawasan hutan lindung. Upaya secara hukum juga bisa dilakukan jika terjadi kesulitan dalam upaya pengembalian fungsi hutan lindung.

Kawasan sempadan sungai dan sempadan mata air terjadi perubahan penggunaan lahan menjadi empang, kebun, sawah, tegalan dan semak belukar, pendekatan secara persuasif dapat dilakukan oleh instansi terkait terhadap masyarakat sekitar sempadan sungai dan mata air untuk tidak memanfaatkannya sebagai kawasan budidaya pertanian, karena penggunaan pupuk dan pesisida dapat menyebabkan pencemaran air dan merusak kualitas air. Kegiatan rehabilitasi pada sempadan sungai yang berupa reboisasi dan pengkayaan jenis tanaman dengan perakaran yang kuat dan tidak merusak struktur tanah dan kualitas air, bertujuan sebagai perlindungan tata air dan pencegahan erosi. Jenis tanaman yang dapat digunakan untuk sempadan sungai antara lain beringin, bambu, vertiver dan rumput gajah. Untuk mengatasi erosi dan sedimentasi koservasi secara sipil teknis dengan membuat dam penahan dan dam pengendali sedimen, serta sumur resapan.

Hutan produksi di Kabupaten Kendal terdiri dari 2 (dua) kawasan yaitu hutan produksi terbatas $(1.112,99 \mathrm{ha})$ dan hutan produksi tetap (15.103,42 ha). Lahan kritis pada hutan produksi terbatas mencapai 927,44 ha sedangkan pada hutan produksi tetap mencapai $6.868,29$ ha. Ketidaksesuaian penggunaan lahan pada kedua kawasan tersebut berupa kebun, sawah, semak belukar, permukiman dan tegalan. Kegiatan rehabilitasi yang dapat dilakukan pada pada kawasan hutan dengan penggunaan lahan berupa permukiman penanganannya sama seperti pada hutan lindung, diperlukan adanya kegiatan sosialisasi dan pendekatan dari instansi terkait terhadap masyarakat setempat untuk tidak menggunakan kawasan hutan sebagai permukiman, serta upaya secara hukum bisa dilakukan jika pendekatan secara persuasif tidak berhasil.

Upaya rehabilitasi pada hutan produksi untuk penggunaan lahan semak belukar, kebun, sawah dan tegalan adalah berupa kegiatan reboisasi dan pengkayaan jenis tanaman hutan. Rehabilitasi lahan dapat dilakukan dengan penerapan teknik konservasi tanah dan air secara sipil teknis seperti pembuatan bangunan dam pengendali, dam penahan, 
terasering, saluran pembuangan air, sumur resapan, embung, rorak (parit buntu), dan biopori. Kawasan hutan produksi di Kabupaten Kendal dikelola oleh Perum Perhutani KPH Kendal, kegiatan pengelolaan hutan dilakukan bersama dengan masyarakat sekitar hutan melalui penerapan sistem PHBM. Diharapkan pengelolaan hutan dengan PHBM di lakukan secara optimal pada kawasan-kawasan hutan yang masuk kategori kategori lahan kritis dengan pengawasan secara ketat, supaya kegiatan pertanian secara tumpangsari tidak merusak tanaman pokok dari hutan produksi tersebut.

Sebaran lahan lahan kritis kawasan budidaya (diluar kawasan hutan) di Kabupaten Kendal meliputi Kecamatan Singorojo, Limbangan, Sukorejo dan Plantungan, Patean, Boja, Pagerruyung, Weleri, Kaliwungu Selatan, Gemuh, Pegandon, Kaliwungu dan Ngampel. Pada kawasan di bagian selatan Kabupaten Kendal, faktor kemiringan lereng dan curah hujan menyebabkan erosi pada lahan perbukitan atau lahan miring sehingga menurunkan kualitas kesuburan tanah. Penggunaan lahan pada kawasan budidaya terbesar adalah kebun, sawah dan tegalan. Kegiatan rehabilitasi yang dapat dilakukan untuk mengatasi lahan kritis di kawasan budidaya adalah melalui reboisasi dan pengelolaan tanah sesuai dengan kaidah konservasi tanah dan air.

Penggunaan lahan kebun tersebar di dataran tinggi bagian selatan Kabupaten Kendal, yaitu Kecamatan Limbangan, Boja, Patean, Pagerruyung, Sukorejo, Plantungan dan Singorojo. Idjudin (2011) mengungkapkan bahwa budidaya perkebunan di dataran tinggi dihadapkan pada faktor pembatas biofisik seperti lereng yang relatif curam, kepekaan tanah terhadap erosi dan longsor dan curah hujan yang tinggi, kesalahan dalam pengelolaan dan pemanfaatan sumberdaya lahan di dataran tinggi dapat menimbulkan kerusakan biofisik berupa degradasi kesuburan tanah dan ketersediaan air. Rehabilitasi vegetatif dengan menggunakan jenis tanaman berakar dalam, dapat menembus lapisan kedap air, mampu meresapkan air ke lapisan lebih dalam, memiliki massa yang relatif ringan dan memiliki nilai ekonomis yang cukup tinggi untuk meningkatkan pendapatan masyarakat setempat. Jenis tanaman yang dipilih untuk kebun campuran adalah sonokeling, kayu manis, cengkih, pala, petai, jengkol, melinjo, alpukat, kakao, kopi, teh dan kelengkeng.

Lahan kritis berupa tegalan paling luas berada di Kecamatan Sukorejo (1.850,93 ha), tepatnya di Desa Bringinsari (637,29 ha), Ngargosari (366,03 ha) Gentingagung (330,79 ha), Tamanrejo (201,88 ha), Pesaren (94,56 ha) dan Harjodowo (7,42 ha). Desa-desa tersebut berada pada kelerengan curam hingga sangat curam dan curah hujan rata-rata $>2500$ $\mathrm{mm} /$ tahun, sehingga potensi terjadinya erosi cukup besar. Pengelolaan lahan secara benar dengan teknik rehabilitasi vegetatif dan sipil teknis seperti untuk mengendalikan longsor atau erosi melalui pembuatan saluran drainase, dam penahan, dam pengendali, sumur resapan, biopori, terasiring, pembuatan banguan penahan material longsor juga harus dilakukan secara tepat. Menurut Dariah (2007), proporsi tanaman tahunan harus semakin besar dengan kemiringan lereng yang semakin tinggi. Konservasi vegetatif dapat dilakukan dengan metode pemilihan dan pengaturan pola tanam, penanaman tanaman penutup tanah, penggunaan tanaman/sisa tanaman sebagai mulsa, sistem alley copping (budidaya lorong), strip rumput, dan wanatani (agroforestry). Penanaman penutup tanah/pupuk hijau seperti Cayanus cayan (gude), Mucuna sp. (benguk), kacang tunggak, atau komak sesudah tanaman pangan, merupakan pengaturan pola tanam yang bisa berdampak positif terhadap perbaikan kesuburan kimia dan biologi serta sifat fisik tanah. Rehabilitasi lahan pada pemukiman juga dilakukan secara vegetatif dan sipil teknis, pada pekarangan-pekarangan pemukiman dapat ditanami dengan tanaman buah dan pembuatan sumur resapan, biopori dan perbaikan saluran drainase.

Kegiatan pengelolaan hutan rakyat dan optimalisasi pembuatan Kebun Bibit Rakyat (KBR) dapat dikembangkan pada kawasan budidaya yang terlantar, seperti pada lahan kosong dan pekarangan. Pemberdayaan kelompok tani diharapkan dapat mempercepat 
proses rehabilitasi melalui pengelolaan hutan rakyat dengan kegiatan penanaman menggunakan jenis tanaman keras, Multi Purpose Trees Species (MPTS) dan buah-buahan.

Tabel 17 Urutan Prioritas Rehabilitasi Lahan Kritis Kabupaten Kendal

\begin{tabular}{|c|c|c|c|c|}
\hline No & $\begin{array}{l}\text { Tingkat } \\
\text { Kekritisan }\end{array}$ & $\begin{array}{l}\text { Kawasan pada pola } \\
\text { ruang }\end{array}$ & $\begin{array}{l}\text { Penggunaan } \\
\text { Lahan }\end{array}$ & Arahan rehabilitasi \\
\hline & Prioritas I & & & \\
\hline \multirow[t]{6}{*}{1} & \multirow{5}{*}{$\begin{array}{l}\text { Sangat } \\
\text { Kritis } \\
\text { Kritis } \\
\text { Agak kritis }\end{array}$} & $\begin{array}{l}\text { Kawasan Lindung } \\
\text { Hutan lindung }\end{array}$ & $\begin{array}{l}\text { Hutan lindung, } \\
\text { Semak belukar, } \\
\text { Permukiman } \\
\end{array}$ & \multirow{5}{*}{$\begin{array}{l}\text { Pada hutan lindung : reboisasi dan } \\
\text { pengkayaan jenis, PHBM, } \\
\text { pendekatan persuasif penertiban } \\
\text { pemukiman atau relokasi } \\
\text { Pada kawasan perlindungan } \\
\text { setempat : Reboisasi dengan jenis } \\
\text { tanaman yang diijinkan, pembuatan } \\
\text { dam penahan dan dam pengendali, } \\
\text { pendekatan persuasif atau relokasi } \\
\text { ke kawasan yang sudah ditunjuk } \\
\text { untuk penggunaan sawah, kebun, } \\
\text { tegalan dan pemukiman } \\
\text { Pada Hutan produksi : reboisasi dan } \\
\text { pengkayaan jenis, PHBM, } \\
\text { pendekatan persuasif penertiban } \\
\text { pemukiman atau relokasi }\end{array}$} \\
\hline & & $\begin{array}{l}\text { Sempadan rel kereta } \\
\text { api }\end{array}$ & Kebun & \\
\hline & & Sempadan sungai & $\begin{array}{l}\text { Empang, } \\
\text { permukiman, } \\
\text { sawah, kebun, } \\
\text { semak belukar, } \\
\text { tegalan }\end{array}$ & \\
\hline & & Sempadan mata air & $\begin{array}{l}\text { sawah, semak } \\
\text { belukar, tegalan }\end{array}$ & \\
\hline & & $\begin{array}{l}\text { Kawasan Budidaya } \\
\text { Hutan produksi tetap } \\
\text { dan hutan produksi } \\
\text { terbatas }\end{array}$ & $\begin{array}{l}\text { Hutan, } \\
\text { permukiman, } \\
\text { sawah, kebun, } \\
\text { semak belukar, } \\
\text { tegalan }\end{array}$ & \\
\hline & $\begin{array}{l}\text { Sangat } \\
\text { Kritis } \\
\text { Kritis }\end{array}$ & $\begin{array}{l}\text { Kawasan Budidaya } \\
\text { tanaman tahunan } \\
\text { tanaman pangan } \\
\text { hortikultura dan } \\
\text { perkebunan } \\
\text { permukiman }\end{array}$ & $\begin{array}{l}\text { permukiman, } \\
\text { sawah, kebun, } \\
\text { semak belukar, } \\
\text { tegalan }\end{array}$ & \multirow{2}{*}{$\begin{array}{l}\text { Reboisasi dengan jenis vegetasi } \\
\text { campuran, hutan rakyat, penanaman } \\
\text { pohon pelindung, tanaman penguat } \\
\text { teras lereng dan tebing sungai, } \\
\text { pengaturan pola tanam, pemupukan, } \\
\text { pembuatan rorak, dam penahan, } \\
\text { dam pengendali, pembuatan sumur } \\
\text { resapan air hujan, embung air, } \\
\text { saluran pembuangan air, penanaman } \\
\text { pohon pada pemukiman dan } \\
\text { pembuatan biopori }\end{array}$} \\
\hline 2 & Agak kritis & $\begin{array}{l}\text { Kawasan Budidaya } \\
\text { tanaman tahunan } \\
\text { tanaman pangan } \\
\text { hortikultura dan } \\
\text { perkebunan } \\
\text { permukiman }\end{array}$ & $\begin{array}{l}\text { permukiman, } \\
\text { sawah, kebun, } \\
\text { semak belukar, } \\
\text { tegalan }\end{array}$ & \\
\hline
\end{tabular}

Pengelolaan hutan rakyat dilakukan untuk memperoleh penutupan lahan secara optimal dalam mengendalikan lahan kritis, konservasi tanah dan tata air serta meningkatkan pendapatan masyarakat lelalui penjualan produk dari hutan rakyat. Kebutuhan masyarakat pada kayu bakar dan kayu bangunan akan dengan mudah terpenuhi tanpa merusak hutan. Pengembangan hutan rakyat model agroforestry berbasis ketahanan pangan, diharapkan dapat memenuhi persediaan pangan masyarakat baik tahunan atau musiman. Diversifikasi produk dan pengurangan risiko gagal panen serta adanya jaminan bahan pangan secara berkelanjutan. Jenis tanaman pangan yang berasal dari hutan dan biasa disinergikan di hutan rakyat antara lain padi ladang, jagung, kacang-kacangan, umbi umbian, dan buah buahan.

Kategori pertanian, kehutanan, dan perikanan yang terdiri atas tanaman pangan, tanaman hortikultura, tanaman perkebunan, peternakan, dan jasa pertanian dan perburuan merupakan sektor andalan karena memberikan sumbangan yang cukup besar dalam pembentukan PDRB Kabupaten Kendal. Secara umum, kategori pertanian, kehutanan, dan perikanan di tahun 2014 ini mengalami perlambatan pertumbuhan menadi 2,50 persen, separuh lebih rendah apabila dibandingkan dengan tahun 2013 yang mengalami pertumbuhan sebesar 4,65 persen. Total nilai produksi kayu jati di Kabupaten Kendal tahun 2014 tercatat 8.089,751 m3 dengan nilai 1,4 milyar rupiah. 
Produksi padi gogo pada Kecamatan Sukorejo, Patean, Singorojo, Boja, Kaliwungu, Kaliwungu Selatan, Brangsong, Pegandon, Ngampel dan Gemuh mengalami penurunan pada tahun 2014 jika dibandingkan dengan produksi tahun 2013, produksi tahun 2014 sebanyak 1.246 ton dengan luas panen 793 ha , sedangkan tahun 2013 sebanyak 5.018 ton dengan luas panen 1.168 ha. Produksi jagung tahun 2014 adalah 214.637 ton dengan luas panen 31.607 ha. Produksi kopi tahun 2014 adalah 1.392 ton dengan luas lahan 3.044 ha. Tanaman perkebunan yang memberikan sumbangan besar dalam perekonomian di Kabupaten Kendal diantaranya adalah teh, karet, kakao, tembakau rakyat, kelapa, tebu rakyat, kopi, aren, kapuk dan cengkeh (BPS Kabupaten Kendal 2014).

Tabel 18 Arahan Pengembangan Wilayah Pada Lahan Kritis Tahun 2014 Di Kabupaten Kendal

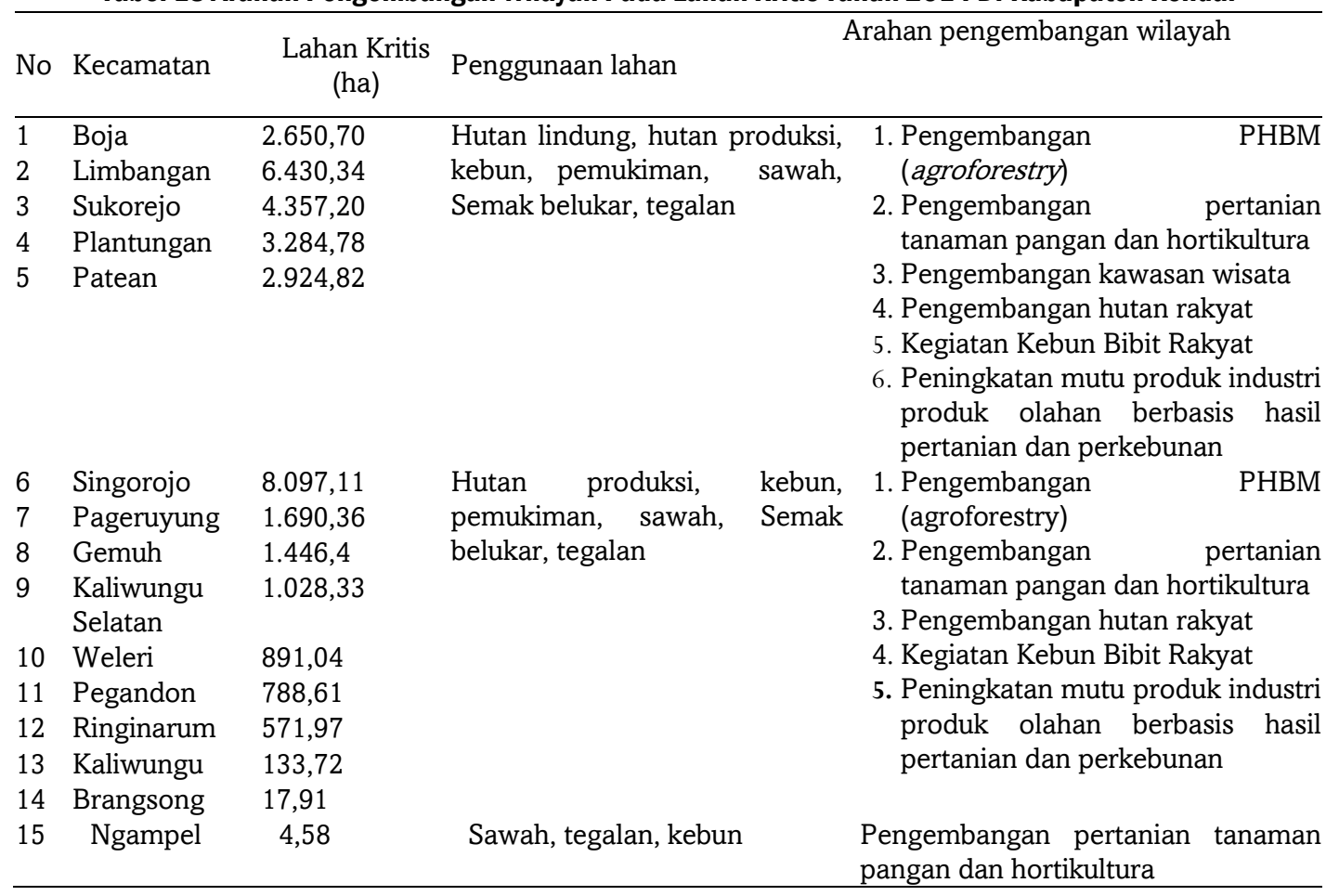

Arahan pengembangan wilayah pada kawasan hutan dapat dilakukan melalui kegiatan Pengelolaan Hutan Bersama Masyarakat (PHBM) dengan pemanfaatan sumberdaya hutan melalui pengembangan agroforestry, ekowisata dan wanafarma. PHBM bertujuan meningkatkan kesejahteraan masyarakat sekitar hutan dan bertujuan untuk menjaga hutan agar terhindar dari kerusakan akibat penebangan liar. Rehabilitasi lahan kritis dengan reboisasi pada kawasan hutan produksi dan pengelolaan lahan dibawah tegakan secara tumpangsari antara tanaman pokok dengan tanaman pangan seperti padi gogo, jagung, kacang tanah, singkong, dan ubi akan menambah peningkatan produksi tanaman pangan dan produksi kayu. Apabila kawasan hutan yang dapat diolah untuk ditanam padi gogo adalah 2.000 ha maka akan menambah produksi \pm 3.000 ton, jika ditanam jagung maka akan menghasilkan \pm 13.400 ton. Apabila lahan yang digunakan untuk menanam kopi seluas 800 ha, maka akan menambah produksi sebesar \pm 400 ton. Melalui PHBM diharapkan akan meningkatkan PDRB dari sub sektor kehutanan, perkebunan dan tanaman pangan di Kabupaten Kendal.

Kegiatan rehabilitasi dan pengelolaan hutan lindung yang dilaksanakan pada hutan lindung di KPH Cianjur, Perum Perhutani Unit III Jawa Barat, pengusahaan tanaman kopi mutu/strata bersama tanaman semusim dan kayu-kayuan memberi hasil yang lebih baik bila dibandingkan dengan kawasan yang hanya didominasi oleh pohon kayu-kayuan 
saja atau hanya tanaman perkebunan dan tanaman semusim saja (Djuariah 2005)11. Menurut Dwiprabowo et al (2011)12, keberhasilan kegiatan tumpangsari yang dilaksanakan pada kawasan hutan di KPH Sukabumi yaitu mampu meningkatkan pendapatan masyarakat setempat dan meningkatkan keuntungan Perum Perhutani karena keberhasilan tanaman yang tinggi sehingga hasil panen kayu lebih tinggi dan keuntungan akan bertambah. Salah satu faktor penting yang menyebabkan tingkat keberhasilan yang tinggi ini adalah partisipasi masyarakat,masyarakat memperoleh bagian seluruhnya dari hasil tumpangsari dan juga sebagian hasil kayu di kemudian hari.

Arahan pengembangan wilayah di lahan kritis pada kawasan tanaman tahunan, kawasan tanaman pangan dan kawasan hortikultura dan perkebunan seluas 20.122,86 ha yang tersebar di Kecamatan Boja, Gemuh, Kaliwungu, Kaliwungu Selatan, Limbangan, Patean, Pageruyung, Plantungan, Ringinarum, Singorojo, Sukorejo dan Weleri melalui pengembangan hutan rakyat dan kegiatan penanaman kebun bibit rakyat (KBR) pada areal lahan kritis milik rakyat dengan kondisi berjurang, kelerengan lebih dari 40\%, lahan yang terlantar dan kawasan disekitar hutan lindung. Struktur hutan rakyat terdiri atas pepohonan menggunakan jenis tanaman MPTS (durian, nangka, sirsak, dll) dan jenis tanaman kayu keras (sengon, jabon, gmelina, dll) dan tumbuhan bawah (kapulaga, porang, lada, ubi jalar dll). Kegiatan tersebut diharapkan dapat mengatasi kekritisan lahan dan meningkatkan meningkatkan produksi tanaman pangan, perkebunan, produksi kayu dan industri.

Untuk meningkatkan pendapatan daerah Kabupaten Kendal dengan mengembangkan kawasan wisata terutama yang berada di Kecamatan Limbangan (sumber air panas di Desa Gonoharjo, kawasan Pemancingan Sekatul di Desa Margosari dan air terjun di Desa Gondang), Boja (pemancingan dan wisata air di desa Ngabean yaitu obyek Wisata Nusantara) dan Singorojo (Curug Lingseng dan Makam Kyai Suropadan, Curug Lawe dan Goa Kiskendo), diupayakan melalui perbaikan sarana transportasi, akomodasi, infrastruktur, pemandu wisata dan tempat penjualan oleh-oleh.

\section{KESIMPULAN}

Simpulan yang didapat dalam penelitian ini adalah luas lahan kritis di Kabupaten Kendal pada tahun 2014 dengan parameter P./V-Set/2013 adalah 19.535,96 ha dan parameter modifikasi 34.317,87 ha. Sebaran lahan kritis tahun 2014 dengan parameter modifikasi terhadap pola ruang (RTRW) menunjukkan bahwa lahan kritis pada kawasan lindung 4.678,92 ha dan pada kawasan budidaya 29.638,95 ha.

Arahan rehabilitasi lahan diutamakan pada kawasan lindung (kawasan hutan lindung dan kawasan perlindungan setempat) dan kawasan hutan produksi (tetap dan terbatas) dengan tingkat kekritisan lahan mulai dari "sangat kritis" hingga "agak kritis". Pada kawasan budidaya di luar kawasan hutan prioritas utama pada kelas "sangat kritis" dan "kritis". Prioritas berikutnya adalah untuk arahan rehabilitasi pada kawasan budidaya di luar kawasan hutan dengan kelas "agak kritis". Kegiatan rehabilitasi lahan secara umum adalah kegiatan konservasi vegetatif (reboisasi, penghijauan, pengkayaan jenis tanaman untuk memperbaiki kesuburan tanah) dan konservasi sipil teknis untuk pencegahan erosi dan sedimentasi (dam pengendali, dam penahan, terasering, saluran pembuangan air, sumur resapan, embung, rorak, dan biopori).

Arahan pengembangan wilayah berdasarkan pemetaan lahan kritis tahun 2014 pada masing-masing kawasan adalah, pada hutan lindung melalui kegiatan PHBM dengan sistem agroforestry, pengembangan hutan rakyat di sekitar hutan lindung, ekowisata dan wanafarma. Pada kawasan lindung di luar hutan melalui pengkayaan jenis tanaman dengan perakaran yang kuatatau tanaman pertanian lain yang diijinkandengan tidak merusak 
struktur tanah dan kualitas air. Pada hutan produksi melalui optimalisasi pengembangan PHBM dengan sistem bagi hasil yang menguntungkan masyarakat dan Perum Perhutani. Pada kawasan budidaya terutama lahan terlantar dan pekarangan melalui optimalisasi kegiatan KBR dan pengembangan hutan rakyat dengan menggunakan jenis tanaman keras, MPTS, dan buah-buahan.

\section{DAFTAR PUSTAKA}

Dariah A, Rachman A, Kurnia U. 2004. Erosi dan Degradasi Lahan Kering di Indonesia. Bogor (ID). Puslittanak Badan Penelitian dan Pengembangan Pertanian, Departemen Pertanian.

Didu MS. 2001. Analisis Posisi dan Peran Lembaga Serta Kebijakan dalam Proses Pembentukan Lahan Kritis. Jurnal Teknologi Lingkungan. 2(1): 93-105.

Dinas Pertanian, Perkebunan dan Kehutanan Kabupaten Kendal. 2014. Statistika Kehutanan. Kendal (ID) : Distanbunhut Jawa Tengah

Kementerian Kehutanan. 2013. Peraturan Direktur Jenderal Bina Pengeloaan Daerah lauran Sungai dan Perhutanan Sosial Nomor : P 4/V-Set/2013 tentang Petunjuk Teknis Penyusunan Data Spasial Lahan Kritis. Jakarta (ID) : Kemenhut.

Hardjowigeno S, Widiatmaka. 2007. Evaluasi Kesesuaian Lahan dan Perencanaan Tataguna Lahan. Yogyakarta (ID) : Gadjahmada University Press.

Badan Perencanaan Pembangunan Daerah Kabupaten Kendal. 2011. Sistem Informasi Status Hara Lahan Pertanian Tembakau Kabupaten Kendal. [internet]. [diacu 8 Agustus 2015]. Tersedia dari :http://bappeda. kendalkab.go.id/lahan/.

Arsyad S. 1989. Konservasi Tanah dan Air. Bogor (ID) : IPB Press.

Kubangun SH. 2015. Model Spasial Bahaya Lahan Kritis di Kabupaten Bogor, Cianjur, dan Sukabumi [tesis]. Bogor (ID): Program Pascasarjana, Institut Pertanian Bogor.

Rustiadi E, Saefulhakim S, Panuju DR. 2006. Perencanaan dan Pengembangan Wilayah, Bogor (ID): Fakultas Pertanian, Institut Pertanian Bogor.

Departemen Kehutanan. 2009. Peraturan Menteri Kehutanan Republik Indonesia Nomor : P. 32/Menhut-II/2009 tentang Tata Cara Penyusunan Rencana Teknik Rehabilitasi hutan dan lahan Daerah Aliran Sungai (RTkRHL-DAS). Jakarta (ID) : Dephut.

Djuariah R. 2005. Studi Kelayakan Pengelolaan Hutan Lindung Bersama Masyarakat : Studi Kasus di Hutan Lindung KPH Cianjur Perum Perhutani Unit III Jawa Barat [tesis]. Jakarta (ID) : Universitas Indonesia.

Dwiprabowo H, Effendi R, Hakim I, Bangsawan I. 2011. Kontribusi Kawasan Hutan dalam Menunjan Ketahanan Pangan : Studi Kasus Propinsi Jawa Barat.Jurnal Analisis Kebijakan Kehutanan. 8(1) : 47 - 61. 